\title{
Archaeological Testing at Sunrise Canyon Subdivision (41BX441), Universal City, Texas
}

Kenneth M. Brown

Follow this and additional works at: https://scholarworks.sfasu.edu/ita

Part of the American Material Culture Commons, Archaeological Anthropology Commons, Environmental Studies Commons, Other American Studies Commons, Other Arts and Humanities Commons, Other History of Art, Architecture, and Archaeology Commons, and the United States History Commons

Tell us how this article helped you.

This Article is brought to you for free and open access by the Center for Regional Heritage Research at SFA ScholarWorks. It has been accepted for inclusion in Index of Texas Archaeology: Open Access Gray Literature from the Lone Star State by an authorized editor of SFA ScholarWorks. For more information, please contact cdsscholarworks@sfasu.edu. 


\section{Archaeological Testing at Sunrise Canyon Subdivision (41BX441), Universal City,}

Texas

\section{Creative Commons License}

(c) (1) (8)

This work is licensed under a Creative Commons Attribution-NonCommercial 4.0 International License 


\section{ARCHAEOLOGICAL TESTING AT SUNRISE CANYON SUBDIVISION (41 BX 441), UNIVERSAL CITY, TEXAS}

Kenneth M. Brown

Center for Archaeological Research

The University of Texas at San Antonio

Archaeological Survey Report, No. 133 


ARCHAEOLOGICAL TESTING AT SUNRISE CANYON SUBDIVISION (4I BX 441),

UNIVERSAL CITY, TEXAS

\author{
Kenneth M. Brown
}

Center for Archaeological Research

The University of Texas at San Antonio ${ }^{\oplus}$

Archaeological Survey Report, No. 133 
A 7 ist of publications offered by the Center for Archaeological Research can be obtained by sending $\$ 1.00$ to the Center for Archaeological Research, The University of Texas at San Antonio, San Antonio, Texas 78285. 


\begin{abstract}
From January 3-7, 1984, a field crew from the Center for Archaeological Research, The University of Texas at San Antonio, consisting of Kenneth Brown, Ralph Snavely, and Margaret Greco spent approximately 12 person-days testing archaeological deposits at Sunrise Canyon subdivision (Unit 2) in Universal City, Bexar County, for Sitterle \& Companies, the developer.

No further field work. is recommended at site 41 BX 441 . While further excavation, at least in the vicinity of Test Pit 1, might augment the collection of artifacts from the site, the geologic setting indicates that the context of deposition would be much the same as a surface collection.

Keywords: archaeology, Bexar County, Guadalupe tools, Plainview points.
\end{abstract}


TABLE OF CONTENTS

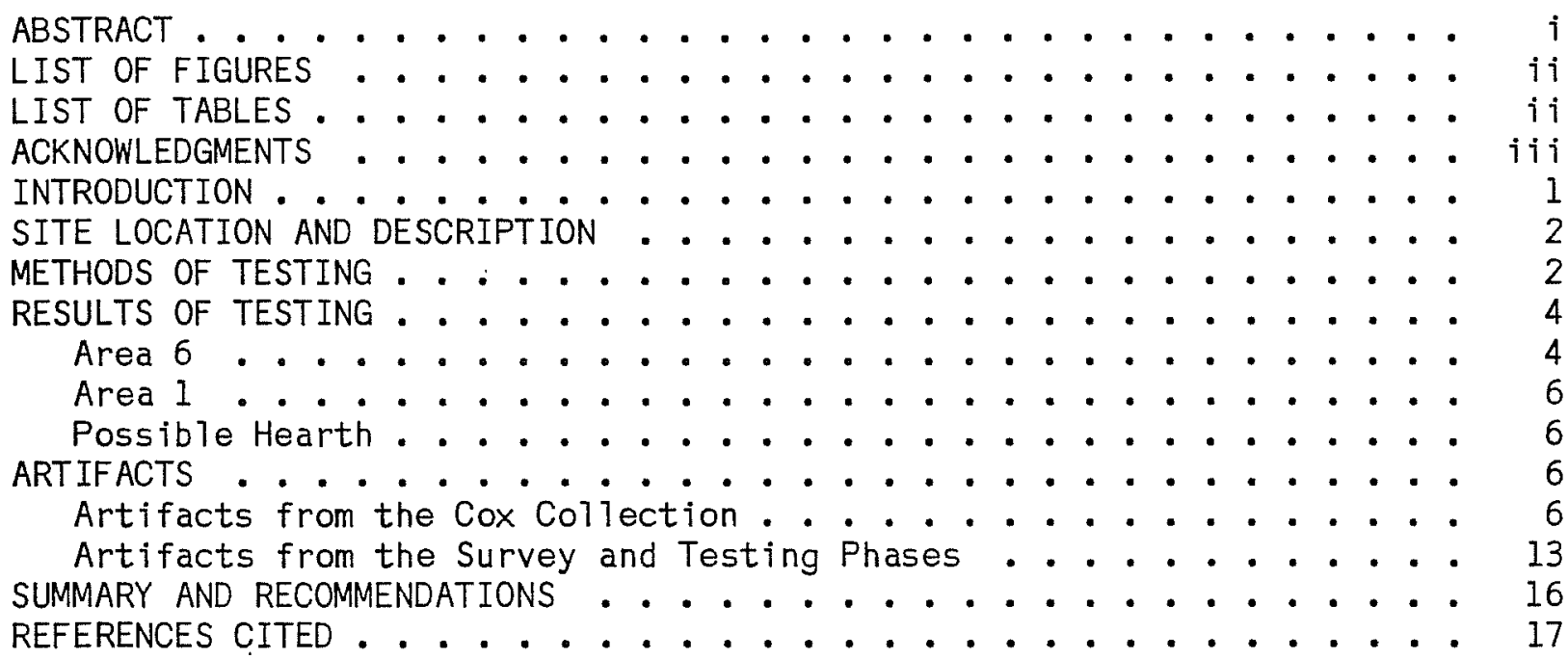

\section{LIST OF FIGURES}

1. The Seibel Site, 41 BX 441 ............... . . 3

2. Artifacts from the Cox Collection and from the Survey and Testing

Phases at the Seibel Site ..............

\section{LIST OF TABLES}

1. Items Recovered from Test Pits in Area 6........... 5

2. Items Recovered from Test Pits in Area 1........... 7 


\section{ACKNOWLEDGMENTS}

The author would 1 ike to thank Ra $1 \mathrm{ph}$ Snavely and Margaret Greco for their help in the field work, and Brian McDonough, Project Engineer for Sitterle \& Companies. 



\section{INTRODUCTION}

From January 3-7, 1984, a field crew from the Center for Archaeological Research (CAR), The University of Texas at San Antonio (UTSA), consisting of Kenneth Brown, Ralph Snavely, and Margaret Greco, spent approximately 12 person-days testing archaeological deposits at Sunrise Canyon subdivision (Unit 2) in Universal City, Bexar County, for Sitterle \& Companies, the developer.

The testing of 41 BX 441 was done fol lowing recommendations provided by Ralph Snavely (1983) in his earlier survey of the properties. These recommendations were in large part prescribed by Patience Patterson, an archaeologist representing the Texas Historical Commission, following an on-site visit. The survey and subsequent testing were done as part of the requirements for a Veterans Administration grant application and is in compliance with the National Historic Preservation Act of 1966 (as amended) and Executive Order 11593. Al1 field work was done under the general supervision of Thomas R. Hester, CAR Director and Jack D. Eaton, Associate Director.

Unit 2, which covers 27 acres (10.9 hectares), is one of several housing developments under construction in the city 1 imits of Universal City. A previously recorded archaeological site, the Seibel site (4I BX 441), extends into the subdivision. The site was originally reported by David Cox in 1977 when he found some artifacts (including two Plainview points) eroding out of a northwest-southeast running gravel road which now forms a utility easement and the northeast boundary of the subdivision. Cox (1977; site survey records on $f i 1 e$, CAR-UTSA) original1y reported the site to be about $100 \times$ $60 \mathrm{~m}$ in extent, roughly bisected by the road, but he also indicated that $\mathrm{Mr}$. Seibel had found artifacts throughout his property.

In November 1983, a survey of the 27 acres in Unit 2 was done by Ra $1 \mathrm{ph}$ Snavely of the CAR. Snavely (1983) was able to define nine different areas of scattered cultural debris, two of them extending northeast across the fence into the Seibel property. Thus, the northeast-southwest extent of the cultural debris is at least $365 \mathrm{~m}$ within the 1 imits of Unit 2 alone, and may extend somewhat into the subdivision to the southwest as we 11.

In both Snavely's report and in this one, all of the archaeological remains in Unit 2 are considered to be part of the Seibel site, even though the area involved is larger than that originally reported by Cox, and the individual debris scatters are discontinuous.

At least two other archaeological sites have been recorded in the vicinity. One site (4I BX 35) located upstream on the floodplain of Cibolo Creek reported $1 y$ has produced Golondrina points and a variety of Middle Archaic and Late Archaic projectile points." Another site (41 BX 401) is a very smal1 quarry site farther upstream, also on the Cibolo Creek floodplain near the western valley margin, located during a sewer 1 ine survey for the Cibolo Creek Municipal Authority (Jaquier 1977). This survey also covered a stretch of the floodplain directiy across from Sunrise Canyon (Area 1), but no sites were located there. 


\section{SITE LOCATION AND DESCRIPTION}

The Seibel site (Fig. 1) is located on the southwest side of Cibolo Creek in the city 1 imits of Universal City, about $500 \mathrm{~m}$ from the present creek channe1. Wildridge Trai1, Spyglass, Broken Spur, Seri Cove, Oak Knob, and Firesage Streets cut through the area covered by the debris scatters. The site is not on a terrace as previously reported (Cox 1977:7) but rather on a 1 arge upthrust block of Pecan Gap Cha1k (Upper Cretaceous) that here rises 80 feet $(24 \mathrm{~m})$ or more above the present floodplain of Cibolo Creek at the southeast edge of the Balcones Escarpment (Bureau of Economic Geology 1974). Because of its elevation, the surface of this fault block (at 808-826 feet above mean sea level [MSL] in Unit 2) has never received any deposition from Cibolo Creek, even during the earlier span of the Quaternary. As a result, whatever soil is present has formed in place through dissolution of the underlying chalk bedrock, not through colluvial or alluvial deposition. This lack of deposition means that most of the site is essentially a surface occurrence, and that any artifacts found beneath the surface in the shallow soil were originally deposited on the surface.

A possible exception is represented by two test pits dug at the south end of the subdivision, in lots 33 and 34 . Here the terrain is a 1 itt 1 e higher (824-828 feet above MSL), with the soil developed on a s1 ightly different stratum of bedrock, and the surface rises gently to the west. Some gradual colluviation may have occurred here, and intact soils 40 to $60 \mathrm{~cm}$ deep were encountered. Elsewhere on the flat surface of the tableland, however, the soil is a thin and very compact, heavy clay loam (Tarrant series; Taylor, Hailey, and Richmond 1966). Scattered 1 imestone nodules were encountered at depths of 20 to $37 \mathrm{~cm}$. Examination of road cuts throughout the subdivision indicates $20 \mathrm{~cm}$ of compact, dark gray brown clay loam over an abrupt transition to 1 imestone or chalk bedrock is typical.

The terrain included in Unit 2 subdivision consists of a large flat-topped ridge, trapezoidal in plan view, between a small ravine to the southeast and a deeper canyon to the west. The former retains a smal1 amount of runoff where dammed by the utility easement road, while the latter has several small ponds behind masonry dams, probably fed by seep springs. The surface of the ridge has a few scattered patches of 1 ive oak with a very heavy understory of mountain iaurel and persimmon, or sometimes a more open understory of frostweed, greenbriar, and sma 111 ive oak seed 1 ings. Open areas support grasses, weeds, mesquite, chinaberry, prickly pear, tasajil10, and yucca. Junipers, elms, and hackberries are found occasionally. Some areas have dense thickets of mountain 1 aurel. The site is pockmarked with quite a few sma 11 holes (termed "looters holes" in Snavely [1983]) where someone has been digging up mountain laurel trees for replanting.

\section{METHODS OF TESTING}

Four 1- $\times 1-m$ test pits were dug; another $1-\times 1-m$ area was cleared where a possible hearth had been reported, and was designated Test Pit 5, although actual excavation was 7 imited to trowel ing and brushing louse fill to a depth of no more than $5 \mathrm{~cm}$. Test pits were oriented on magnetic north and were excavated in $10-\mathrm{cm}$ levels, measured from the surface of the southwest corner. 
This page has been

redacted because it

contains restricted

information. 
For screening, a 1/4-inch mesh was used, a though in practice it was impossible to pass all of the heavy clay peds through the screen. Irreducible peds were broken up as finely as possible, searched, and then dumped. Level notes were filled out for each level, and the completed unit was photographed before backfilling. Chipping debris, fire-cracked chert or 1 imestone, and snail shel1s were collected.

Following recommendations by Snavely (1983) two areas that appeared to have the greatest soil depth were tested, as follows:

$\begin{array}{lll}\text { Area } 1 & \text { lot } 55 & \text { Test Pit 1 } \\ \text { Area } 6 & \text { lots } 53,54 & \text { Test Pit } 3 \\ & \text { lot } 34 & \text { Test Pit 2 } \\ & \text { lot } 33 & \text { Test Pit 4 }\end{array}$

Test pits were placed within the areas where vegetation al 1 owed and where soil had not been disturbed by construction activities.

Substantial areas of the site appear to have been disturbed by construction activity. In addition to the roads, which have completely removed the soil profile down into bedrock, other areas have been bulldozed to clear brush, and below-ground utilities have been installed.

\section{RESULTS OF TESTING}

\section{Area 6}

Area 6 is in an eastward-sloping old pasture, now grown over with thin grass cover and scattered medium-sized junipers. Two test pits were dug in Area 6: Test Pit 2 upslope in 1 ot 34 and Test Pit 4 down slope in 1 ot 33 . Some areas were heavily littered with snails, but many of these appeared to be of recent origin. A few shel 15 of Rumina decollata, an $01 d$ World species introduced in recent historic times, were found at 0-20 cm. Collections from the surface of the two squares show a disproportionate number of snails (probably recent) on the surface (Table 1). In Test Pit 2 there are dec 1 ining numbers of Helicina orbiculata, an arid-tolerant species, and slightly increasing numbers of Polygyra sp. from the surface to $30 \mathrm{~cm}$ in depth, perhaps indicating increased ground cover in the past. A slight but definite increase in cultural debris at 20-30 cm suggests there has been some colluviation in this area. Test Pit 4 has much less cultural debris and no indication of a buried cultural stratum. Both test pits were terminated when abundant chalk nodules appeared, signalling bedrock was approached. No artifacts other than a sma11 amount of chipping debris was found in the test pits.

Part of the base and wall of a smal1 (one gallon?) salt-glazed stoneware crock and an ironstone (teapot?) body sherd were found on the surface in lot 35; a neck sherd from an amethyst glass bott le, with a mold seam 1 ine running onto the 1 ip (post-1903) was found on the surface in 1ot 36 . These suggest post-1900 historic activity, perhaps associated with the old road that ran west of Area 6. 
TABLE 1. ITEMS RECOVERED FROM TEST PITS IN AREA 6

$\begin{array}{llll}\text { Rabdotus Helicina Polygyra } & \begin{array}{l}\text { Rumina Praticolella cf. Succinea chert fire-cracked } \\ \text { decollata berlandieriana }\end{array} \\ \text { sp. } & \text { orbiculata sp. } & \begin{array}{l}\text { flakes/ chert } \\ \text { frags. }\end{array}\end{array}$

\begin{tabular}{|c|c|c|c|c|c|c|c|c|}
\hline $\begin{array}{l}\text { Test Pit } 2 \\
\text { surface } \\
0-10 \mathrm{~cm} \\
10-20 \mathrm{~cm} \\
20-30 \mathrm{~cm} \\
30-40 \mathrm{~cm} \\
40-50 \mathrm{~cm} \\
50-55 \mathrm{~cm}, \\
\text { west half }\end{array}$ & $\begin{array}{r}56 \\
94 \\
26 \\
50 \\
36 \\
27 \\
0\end{array}$ & $\begin{array}{r}130 \\
74 \\
14 \\
11 \\
2 \\
0 \\
0\end{array}$ & $\begin{array}{r}11 \\
12 \\
13 \\
26 \\
2 \\
0 \\
0\end{array}$ & $\begin{array}{l}1 \\
1 \\
0 \\
0 \\
0 \\
0 \\
0\end{array}$ & $\begin{array}{l}0 \\
0 \\
1 \\
0 \\
0 \\
0 \\
0\end{array}$ & $\begin{array}{l}0 \\
0 \\
0 \\
0 \\
1 \\
0 \\
0\end{array}$ & $\begin{array}{r}1 \\
0 \\
9 \\
17 \\
4 \\
0 \\
0\end{array}$ & $\begin{array}{l}0 \\
0 \\
1 \\
2 \\
0 \\
0 \\
0\end{array}$ \\
\hline Total & 289 & 231 & 64 & 2 & 1 & 1 & 31 & 3 \\
\hline $\begin{array}{l}\text { Test Pit } 4 \\
\text { surface } \\
0-10 \mathrm{~cm} \\
10-20 \mathrm{~cm} \\
20-30 \mathrm{~cm} \\
30-40 \mathrm{~cm}\end{array}$ & $\begin{array}{r}44 \\
49 \\
0 \\
36 \\
28\end{array}$ & $\begin{array}{r}54 \\
116 \\
1 \\
4 \\
0\end{array}$ & $\begin{array}{l}5 \\
3 \\
0 \\
2 \\
3\end{array}$ & $\begin{array}{l}4 \\
1 \\
0 \\
0 \\
0\end{array}$ & $\begin{array}{l}3 \\
2 \\
0 \\
0 \\
0\end{array}$ & $\begin{array}{l}0 \\
0 \\
0 \\
1 \\
0\end{array}$ & $\begin{array}{l}1 \\
3 \\
1 \\
3 \\
4\end{array}$ & $\begin{array}{l}0 \\
1 \\
0 \\
0 \\
0\end{array}$ \\
\hline Total & 157 & 175 & 13 & 5 & 5 & 1 & 12 & 1 \\
\hline TOTAL & 446 & 406 & 77 & 7 & 6 & 2 & 43 & 4 \\
\hline
\end{tabular}

* This level also has significant quantities of small unaltered limestone nodules and small frost-pitted chert nodules, more than the other levels. 
Area 1

Both test pits in Area 1 were under 1 ive oak motts. Despite the improved she 1 ter, the number and diversity of the snail fauna are great 1 y reduced. The soil here is much thinner and has formed in place. A moderate quantity of chipping debris (Tab1e 2) was found in Test Pit 1, diminishing rapidly with depth. Most of the debris was found in the A horizon, $0-20 \mathrm{~cm}$; bel ow $20 \mathrm{~cm}$ the organic content of the soil diminishes dramatically, and the clay content and compaction increase. Two core remnants, some unifacially edgeretouched flakes, and a possible Ensor point base fragment(?) were the only artifacts recovered. In Test Pit 3 , the soil was even thinner (scattered 1 imestone $\mathrm{flagstones}$ were encountered at $16-18 \mathrm{~cm}$ ), and cultural debris was very scarce; a core and two edge-retouched flake fragments were recovered.

Four artifacts were collected from the surface in or near Area 1: the probable proximal end of a Guadalupe tool, and two large biface preform rejects were found in lot 53. A possible perforator was found in 1 ot 55 .

\section{Possible Hearth (Test Pit 5)}

A $1-\times 1-m^{2}$ (Test Pit 5) was 1 aid out over a possible hearth reported by Snavely (1983; Area 7), and the 100 se fill was removed by troweling and brushing to a depth of $5 \mathrm{~cm}$ or less, then the rock cluster was photographed.

Clearing revealed the maximum size of the rocks is about $8 \times 12 \mathrm{~cm}$; most are about 6 or $7 \mathrm{~cm}$ 1ong. Most are unfractured, a 7 though a few have been cracked in place. Fill is light gray brown clay loam. No charcoal is visible in the fil1, although one smal1 fleck was noted during excavation. The principal concentration is about $65 \mathrm{~cm}$ in diameter although additional rocks extended to the $1 \mathrm{imits}$ of the square. No discoloration of the 1 imestone was noted. These observations seem to indicate this is a natural concentration of rocks rather than a prehistoric hearth.

\section{ARTIFACTS}

Although both Cox (1977) and Snavely (1983) have published brief descriptions of artifacts they collected, I have taken the opportunity to reexamine their collections and provide further details. The Cox collection will be 1 isted first, then the combined collections from the survey and testing phases will be described.

\section{Artifacts from the Cox Collection}

Plainview Basal Fragment (Fig. 2,a)

A basal fragment is made of white chert with a slight grayish tint (or else has patinated to that color; no recent breaks are present). The following sequence of damage and attempted maintenance seems to be indicated: (1) the distal end was removed by an oblique transverse snap originating from one face and rolling up onto the opposite face; (2) subsequently an attempt was 
TABLE 2. ITEMS RECOVERED FROM TEXT PITS IN AREA 1

\begin{tabular}{|c|c|c|c|c|c|c|c|}
\hline & $\begin{array}{l}\text { Rabdotus } \\
\text { sp. }\end{array}$ & $\begin{array}{l}\text { Helicina } \\
\text { orbiculata }\end{array}$ & $\begin{array}{l}\text { Polygyra } \\
\text { sp. }\end{array}$ & $\begin{array}{l}\text { chert } \\
\text { flakes }\end{array}$ & $\begin{array}{l}\text { fire-cracked } \\
\text { chert }\end{array}$ & $\begin{array}{l}\text { fire-cracked } \\
\text { limestone }\end{array}$ & $\begin{array}{c}\text { miscellaneous } \\
\text { items }\end{array}$ \\
\hline \\
\hline $0-10 \mathrm{~cm}$ & 0 & 34 & 0 & 91 & 22 & 3 & $\begin{array}{l}1 \text { core remnant } \\
1 \text { edge-retouched flake frag. } \\
\text { unident. snail, possibly } \\
\text { Mesodon sp.? }\end{array}$ \\
\hline $10-20 \mathrm{~cm}$ & 0 & 1 & 0 & 57 & 14 & 0 & $\begin{array}{l}1 \text { core remnant } \\
2 \text { edge-retouched flakes } \\
1 \text { possible Ensor base frag. }\end{array}$ \\
\hline $\begin{array}{l}20-30 \mathrm{~cm} \\
30-36 \mathrm{~cm}\end{array}$ & $\begin{array}{l}0 \\
0\end{array}$ & $\begin{array}{l}0 \\
0\end{array}$ & $\begin{array}{l}0 \\
0\end{array}$ & $\begin{array}{l}0 \\
0\end{array}$ & $\begin{array}{l}6 \\
2\end{array}$ & $\begin{array}{l}0 \\
0\end{array}$ & \\
\hline \multicolumn{8}{|l|}{ Test pit 3} \\
\hline $\begin{array}{l}0-10 \mathrm{~cm} \\
10-20 \mathrm{~cm}\end{array}$ & $\begin{array}{l}0 \\
2\end{array}$ & $\begin{array}{r}27 \\
0\end{array}$ & $\begin{array}{l}8 \\
0\end{array}$ & $\begin{array}{l}9 \\
2\end{array}$ & $\begin{array}{r}11 \\
3\end{array}$ & $\begin{array}{l}0 \\
1\end{array}$ & $\begin{array}{l}2 \text { edge-retouched flake frags. } \\
1 \text { core }\end{array}$ \\
\hline TOTAL, & 2 & 62 & 8 & 159 & 58 & 4 & 9 \\
\hline
\end{tabular}


Figure 2. Artifacts from the Cox Collection and from the Survey and Testing Phases at the Seibel Site.

$a, b$, Plainview proximal fragments (arrows indicate direction of burin blows or attempted retouch);

c, proximal fragment of a thinned biface;

d, dril1 fragment;

e, basal fragment of an expanding stem dart point;

$f$, retouched flake;

g, biface thinning failure;

$h$, distal fragment of a thinned biface;

$i, i^{\circ}$, Guadalupe tool (dorsal and ventral views, bit at top);

$j, k$, thick bifaces;

$1,1^{\circ}$, possible proximal fragment of a Guadalupe tool;

$m$, possible Guadalupe tool or thick biface;

$n$, core ( $p$ latform at top).

Note: Items $a-d$ and $h$ are from the Cox collection. 

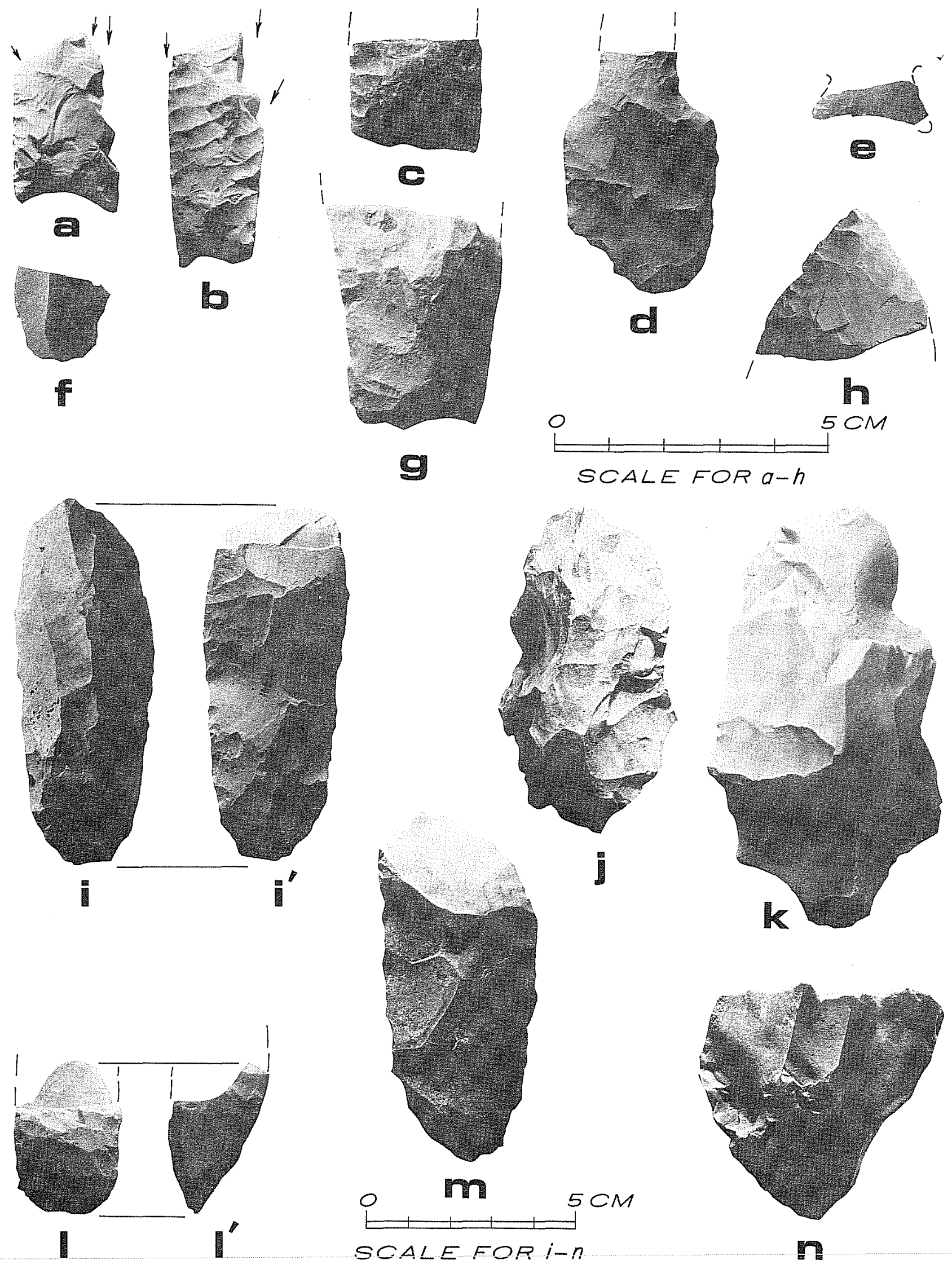

n 
made to rework the left corner by bifacially retouching the left edge, proceeding distally onto the snap facet. This attempt failed because the retouch flakes were too short; (3) an attempt to use the snap facet as a platform to drive off flakes toward the proximal end was also made; apparently this followed event \#2, since a couple of very small flake scars appear to truncate the 1 ast scar created in event \#2. The face from which they were removed is, of course, the one without the rolled out edge; (4) using the snap facet as a platform, the right edge of the fragment was mostly removed by an irregular burin blow which hinged out about $7 \mathrm{~mm}$ short of the basal ear; (5) subsequent burination attempts using the same point of impact battered the right corner and left a highly irregular and jagged edge.

Despite the extensive reworking some details of the original craftsmanship can be observed. The point appears to have been thinned by large, flat softhammer thinning flake scars that are visible in the center of each face but have been removed along the edge by subsequent edge retouching. Part of one of these scars is at least $12.5 \mathrm{~mm}$ wide. On the other face a 1 arge $\mathrm{flake}$ scar is oriented obliquely, having travelled distally and toward the opposite side, hinging out near the opposite edge. It is also about $12.5 \mathrm{~mm}$ wide near the termination. The maximum length of this scar would have been at least $17.5 \mathrm{~mm}$. Of the three manufacturing trajectories proposed by knudson (1983:24-25), this artifact seems to resemble her Plainview Variety II most closely.

Apparently pressure retouch of the lateral edges was done next, although as noted below in a few cases small edge retouch scars overlap basal thinning scars. In general the sequence seems to be: (1) thinning; (2) edge retouch; (3) basal shaping and thinning; (4) edge grinding (may precede step \#3?).

Edge retouch scars are general1 y $4 \mathrm{~mm}$ long or less and for the most part about 2.0 to $3.5 \mathrm{~mm}$ wide, most commonly about $2.5 \mathrm{~mm}$ wide. Edge grinding covers a 11 the unmodified remainder of both edges $(22.6 \mathrm{~mm}$ on one edge, 7.0 $\mathrm{mm}$ on the other). Grinding covers basal ears but does not extend into the basal concavity.

Basal thinning is bifacial; on each side three or four 1 arge pressure retouch scars were removed, then a series of much smaller pressure flake scars were taken off (or at least attempted), evidently to shape the basal edge to the haft. One side has four rather prominent scars, giving it a somewhat fluted appearance. From left to right the maximum length, width, and shape are as fol1 lows (measurements in $\mathrm{mm}$ ): 6.62, 4.5, indeterminate; 14.02, 10.12, expanding; $6.86,3.6$, para 11 e1-sided; $15.28,3.7$, para11e1-sided. On this side of the point the final shaping removals were al1 unsuccessful, resulting in short (maximum length about 0.7 to $1.1 \mathrm{~mm}$ ) abrupt step fractures.

The other side of the point has three basal thinning scars, up to $9.78 \mathrm{~mm}$ 1 ong, the proxima 1 portions of which have been removed by many (perhaps 14 or 50) smal1 shaping scars no more than about $3.2 \mathrm{~mm}$ long; these are quite shallow, with feathered terminations.

Measurements. Maximum length: $32.46 \mathrm{~mm}$; Maximum width: $19.58 \mathrm{~mm}$; Maximum thickness: $5.22 \mathrm{~mm}$; Basai width: $17.26 \mathrm{~mm}$; Depth of basal concavity: $2.40 \mathrm{~mm}$. 
Plainview Proximal Fragment (Fig. 2,b)

A proximal fragment is made of heavily patinated chert, probably originally gray brown, and is narrower, thicker, and more lenticular in cross section than the other specimen, with paralle1-collateral flaking present on both faces, and in these respects conforms to Knudson's (1983:25) Variety III Plainview points. The lateral edges contract 51 ightiy toward the base and are slightly convex. The base is concave, but less so than in the other Plainview point.

The sequence of damage to this point is quite similar to that shown by the other specimen: (1) the distal end was removed by an oblique transverse snap which rolled up onto one face to end with a hinge fracture in front of a sma 11 knot which the craftsman had been unable to remove; (2) at least two attempts to burinate one of the 1 ateral edges were made, the first burin scar originating from the snap facet and traveliing $12.16 \mathrm{~mm}$ before turning out toward the edge at an obtuse angle; the second burin scar is on 7 y $3.64 \mathrm{~mm}$ long and apparently employed the distal end of the first scar as a platform, a though this is not certain; (3) another very sma 11 (2.56 mm 1 ong) burin facet is present on the opposite edge, having failed because the platform angle was too obtuse; (4) on the more acute edge formed by the snap facet, severe battering and step fracturing are visible, along with some rounding of both battered and unmodified sections of the edge. Evidently these represent further attempts to rework the point, and the edge may have been scrubbed with an abrader during the process; (5) some damage to one of the basal ears is also present.

Unlike the first specimen this point shows no remnants of the original softhammer thinning scars; both faces are covered with diagonal parallel pressure flake scars reaching to the midline of the point, although on the more acutely ridged face the midline is offset to one side, probably because of the knot mentioned earlier. These narrow, paral1e1-sided scars vary from 2.40 to $4.70 \mathrm{~mm}$ in width and 7.54 to $14.38 \mathrm{~mm}$ in 7 ength on one side and from 1.84 to $5.56 \mathrm{~mm}$ in width and 7.52 to $10.60 \mathrm{~mm}$ in 1 ength on the other.

One face has four major basal thinning (pressure) scars which clearly truncate several of the 1 ateral scars and end in shallow step terminations; these are 6.86 to $12.52 \mathrm{~mm}$ long and about 2.5 to $5.28 \mathrm{~mm}$ wide at the termination, parallel-sided to slightly expanding in shape. The sequence is indeterminate. The opposite side has three basal thinning scars, in sequence right, left, then middle, a 11 ending in hinge terminations; they are 9.86 to $12.90 \mathrm{~mm}$ long and about 2.0 to $6.52 \mathrm{~mm}$ wide at the termination.

Grinding covers the undamaged basal ear but does not extend into the basal concavity. The longer edge is ground $30.96 \mathrm{~mm}$ from the base, while the opposite edge has a ground edge $24.38 \mathrm{~mm} 1$ ong interrupted by the damaged basal ear and by the burin scar at the distal end.

Measurements. Maximum length: $42.52 \mathrm{~mm}$; Maximum width: $17.90 \mathrm{~mm}$; Maximum thickness: $6.56 \mathrm{~mm}$; Basal width: $14.02 \mathrm{~mm}$; Depth of basal concavity: $1.24 \mathrm{~mm}$. 
Proximal Biface Fragment (Fig. 2,c)

A proximal end of a smal 1 biface is made of brown chert that has partial 1 y patinated to a light blue gray color. The base and sides are straight, and the distal end has been removed by a transverse snap rolling onto one face. Both sides have been thinned and shaped by what appear to be pressure flake scars; basal thinning scars are primarily confined to one face. This specimen was termed an "early man" point in Cox (1977) but there is no diagnostic evidence for such a designation; contrary to the earlier report, there is no evidence of intentional grinding on the edges. This specimen conceivably might be a Plainview Variety III (Knudson 1983:25) preform that broke during manufacture and was discarded because the basa 1 part was too short to rework. If so, then at least two stages of basal thinning would be involved in manufacture, since the previously described points seem to indicate that final basal thinning occurred close to the end of the manufacturing sequence.

Measurements. Maximum length: $21.36 \mathrm{~mm}$; Maximum width: $24.58 \mathrm{~mm}$; Maximum thickness: $6.54 \mathrm{~mm}$; Basal width: $23.30 \mathrm{~mm}$.

Ensor (2 specimens, not illustrated)

One specimen has a very broad, straight-based stem with shallow side notches and angular shoulders, but without barbs. The base is fully as wide as the blade at the shoulders. The basal edge turns distally at each corner. This distinct broad-stemmed, short point may be a distinct Ensor variety not formally recognized yet. It resembles Ensor Variety $F$ points from the $0 b 1$ ate site, for example (Johnson, Suhm, and Tunnell 1962:90; Fig. 33,K,L). Dimensions given below are only approximate since the specimen is encased in Tucite and cannot be measured directly.

Measurements. Maximum length: $34.5 \mathrm{~mm}$; Maximum width: $27.5 \mathrm{~mm}$; Maximum thickness: $5 \mathrm{~mm}$; Stem neck width: $21 \mathrm{~mm}$.

The other Ensor specimen has a 1onger, narrower blade, again with angular shoulders, and an expanding stem that is narrower than the blade width at the shou Tders; the base is straight. Both of these points are missing sma 11 segments from the distal end. This specimen is also encased, and the measurements are approximate.

Measurements. Maximum length: $42 \mathrm{~mm}$; Maximum width: $22.5 \mathrm{~mm}$; Maximum thickness: $5 \mathrm{~mm}$; Stem neck width: $11.5 \mathrm{~mm}$.

Drill (Fig, 2,d)

A medial biface fragment of brown chert (showing slight patina) has been apparentiy reworked into a drill. The proximal end has been thermally fractured, removing the base, and the distal end of the drill tip has been removed by a transverse snap. There is no clear evidence of rotary use wear visible at $40 x$, but it would perhaps not be expected so close to the haft 
element in any case. Both faces, however, show slight but definite polish on flake scar ridges, both on the drill tip remnant and on the haft element, and occasionally on the edges. Pol ish on the edges is restricted to a few very sma 11 areas, overlying moderate to heavy battering and rounding.

Measurements. Maximum Tength: $43.52 \mathrm{~mm}$; Maximum width: $27.62 \mathrm{~mm}$; Maximum thickness: $8.10 \mathrm{~mm}$.

Distal Biface Fragment (Fig. 2,h)

A distal fragment of a thinned biface made of banded 1 ight brown and white chert shows a diagonal transverse snap and may have been broken during manufacture.

\section{Artifacts from the Survey and Testing Phases}

The combined collection from both the survey by Snavely and the more recent testing (including some artifacts found on the surface during testing) is described below.

\section{Expanding Stem Dart Point Basal Fragment (Fig. 2,e)}

The basal edge from the expanding stem of a smal1 dart point is most 1 ikely from an Ensor, but may possibly be from some other type such as Fairland or Edgewood with a similar stem shape. It is made of 1 ight gray brown chert.

Measurement. Basal width: $21.40 \mathrm{~mm}$.

Erovenience: Test Pit 1, level $2(10-20 \mathrm{~cm})$.

Thinned Biface Fragments (2 specimens; one illustrated, Fig. 2,g)

One specimen is a small oblong (basal?) fragment of a biface, broken at one end by thermal fracturing, and subsequently heavily patinated to a 1 ight blue gray color. The specimen was recovered by Snavely (1983) from the surface of house lot $\# 8$.

Another specimen is a 1 arger medial biface section of tan, coarse-grained chert with milky 1 ight blue, brown, and gray inclusions. It has a knot on one face that the craftsman was unable to remove and appears to be a hardhammer preform failure, thermally damaged at one end (Fig. 2,g).

Provenience: Snavely (1983) collection, surface, house lots \#18-19.

Guadalupe Tools (2 specimens, Fig. $2, i, i^{\circ}, 1^{\prime}, 7^{\circ}$ )

One complete Guadalupe tool ( $F$ ig. $2, i, i^{\circ}$ ) was found on the surface in house lot \#65 on the northwest $f 7$ ank of Unit 2. It is made of 1 ight gray brown 
chert that has patinated heavily to an off-white color. A recent break shows the patination rind is $0.9-1.2 \mathrm{~mm}$ thick. No cortex is present. This tool resembles others from south Texas examined as part of a study of Guadalupe tool caches (Brown in press). Terms for tool 1 andmarks and measurements are patterned after that study. In size and shape this tool is very close to the average for the Granberg cache, and is much smaller than the tools from the Lindner cache in Medina County.

The ventral face is gently concave from front to back. The dorsal ridge has been removed by a long, narrow flake scar originating from the bit facet and travelling nearly al1 the way to the proximal end, hinging out just short of the end. This may be a bit rejuvenation scar. The bit is strongly arched, somewhat pointed in shape. The bit facet is slightly canted to the left when $v$ iewed from the ventral face. At $20 x$ the central part of the bit edge appears pristine, evidently because of the removal of two or three rejuvenation flakes shortly before the tool was discarded. Of the remaining part of the bit edge, part has been removed by recent damage; the rest shows heavy battering with stacked step fractures in an area about $10.5 \mathrm{~mm}$ wide, along with other segments that are pristine or moderately rounded and battered.

Both 1 ateral edges vary from sharp to moderately battered. Unlike nearly all of the tools in the Lindner and Granberg caches, there is no evidence of intentional smoothing of the 1 ateral edges.

Measurements. Dorsal 1ength: $90.28 \mathrm{~mm}$; Ventral 1ength: $74.24 \mathrm{~mm}$; Maximum bit width: $30.08 \mathrm{~mm}$; Maximum tool width: $35.62 \mathrm{~mm}$; Maximum thickness: $22.70 \mathrm{~mm}$; Bit thickness: $25.26 \mathrm{~mm}$; Maximum depth of bit concavity: $1.16 \mathrm{~mm}$; Facet/ventral angle: $120^{\circ}$; Bit spine-plane angle: $56^{\circ}$; Weight: $72.5 \mathrm{~g}$.

Provenience. Snavely (1983) collection, surface, house lot \#65.

The second specimen (Fig. $2,7,7^{\circ}$ ) is tentative 1 y identified as the proximal end of a Guadalupe tool removed by an overshot rejuvenation flake. Evidently a rejuvenation blow was directed at the bit edge using the bit facet as a platform; the fracture plane evidently turned inward near the proximal end, emerging on the ventral face of the tool. This fragment represents the distal end of that $f 1$ ake. Other examples of this $k$ ind of breakage are presented in Brown (in press). This specimen is made of 1 ight brown chert. The ventral face of the tool bears several small hard-hammer flake scars.

At $20 x$ one 1 ateral edge appears battered, while the other shows moderate rounding and smoothing. The intersection of the ventral face of the original tool and the ventral face formed by the rejuvenation flake shows battering and a couple of hinge fractures indicating an attempt to rework this smal1 fragment after it was removed from the parent tool.

Measurement. Maximum width: $26.76 \mathrm{~mm}$.

Provenience. Surface, house lot $\# 53$. 
Possible Perforator (?; not illustrated)

This is a large, heavy percussion secondary flake that has been bifacially hard-hammer retouched, apparently to a pointed tip which has been removed by a transverse snap. Much of the cobble cortex still remains on the dorsal side. At 20X, both edges appear mostly pristine; some smal1-scale retouch is present on one edge, but may be manufacturing damage.

Provenience. Surface, house lot $\$ 53$.

Thick Bifaces (4 specimens; three illustrated, Fig. 2,j,k,m)

Three large, thick chert bifaces partially reduced by hard-hammer percussion were found on the surface. One is apparently made from a large flake. A1 1 three lack cortex and have sinuous edges with deep, irregular flake scars. These probably represent bifaces discarded because of an inability to thin them adequate $1 y$.

A fourth biface of patinated 7 ight gray brown chert is more carefully made and has a triangular cross section; it may be a Guadalupe tool with the bit removed by a percussion blow directed at the dorsal ridge (Fig. $2, \mathrm{~m}$ ). The lateral edges are moderately battered.

Measurements. Maximum 1ength: 108.94, 109.50, 84.04, $86.44 \mathrm{~mm}$; Maximum width: $82.66,61.20,48.32,37.66 \mathrm{~mm}$; Maximum thickness: 47.66, 33.66, $27.26,26.76 \mathrm{~mm}$.

Provenience. Snavely (1983) collection, surface, house lot $\# 70$; and surface, house lot \#35 (2 specimens); Snavely (1983) collection, surface, house lot \#34.

Cores (4 specimens; one illustrated, Fig. $2, n$ )

Two matching fragments of a core were found in one of the test pits. This is a large quartered chert cobble with several hard-hammer flake scars, some of which are patinated to a light blue color. The core has been split into two sections by a blow delivered on a flat, cortex-covered side.

Measurement. Weight: $481.1 \mathrm{~g}$.

Provenience. Test Pit 5, level $1(0-5 \mathrm{~cm})$.

One specimen ( $F$ ig. $2, n$ ) is a smal 1 section of a cobble or nodule with three flake removals visible from a prepared platform. The flake facets are patinated to a cream color, but recent damage shows the interior color is light gray brown.

Measurement. Weight: $150.9 \mathrm{~g}$.

Provenience. Test Pit 3, level $2(10-20 \mathrm{~cm})$. 
Another specimen is a sma 11 chert chunk, probably a remnant of a 1 arger core, with a small patch of cortex remaining, and several hard-hammer flake scars visible.

Measurement. Weight: $29.2 \mathrm{~g}$.

Provenience. Test Pit 1 , level $2(10-20 \mathrm{~cm})$.

The fourth specimen is a section of a small cortex-covered nodule with several bifacial hard-hammer flake removals.

Measurement. Weight: $91.6 \mathrm{~g}$.

Provenience. Test Pit 1 , level I $(0-10 \mathrm{~cm})$.

Edge-Retouched Flakes (5 specimens; one illustrated, Fig. 2,f)

Five interior $f l a k e$ fragments recovered from the test pits have some edge damage, ranging from fine scalar retouch to irregular serrations. Nearly al1 the retouch occurs on the dorsal surface of the flakes.

Provenience. Test Pit l, level 1 (I specimen); level 2 (2 specimens); Test Pit 3, level I (2 specimens).

\section{SUMMARY AND RECOMMENDATIONS}

Four test pits were excavated and a possible hearth was investigated at the Seibel site. The geologic context of the site indicates there has never been any deposition on the surface of this high fault block overlooking Cibolo Creek, although test pits in Area 6 indicate some colluviation there. Cultural debris was uncommon in all of the test pits except Test Pit 1, where part of a possible Ensor point, three edge-retouched flakes, two core remnants, and 148 pieces of chipping debris were recovered. The concentrations of cultural debris defined by Snavely seem to cluster roughly along the flanks of the two drainages bordering the subdivision, al though Area 1, which we tested, is 1 located about $200 \mathrm{~m}$ from either one. The topographic setting of the site, high atop a rocky bench, well removed from major sources of water and unprotected except by existing vegetation, is somewhat unusual, but the function of the site cannot be identified from the available information. Documented artifact collections from the site include two Plainview points, two Ensor points and possibly part of a third, one complete Guadalupe tool, and a possible overshot rejuvenation flake fragment from another, two possible perforators, and some waste material from stone tool production (cores, flakes, biface preform rejects).

No further field work is recommended at the Seibel site. While further excavation, at least in the vicinity of Test Pit 1, might augment the collection of artifacts from the site, the geologic setting indicates that the context of deposition would be much the same as a surface collection. If further documentation of the site is desirable, more information might be acquired at less cost by recording Mr. Seibel's artifact collection. 


\section{REFERENCES CITED}

Brown, K. M.

in press Three Caches of Guadalupe Tools from South Texas. Bulletin of the Texas Archeological Society 56.

Bureau of Economic Geology

1974 Geologic Atlas of Texas. San Antonio Sheet. Bureau of Economic Geology, The University of Texas at Austin.

Cox, D.

1977 A Preliminary Report on 'Early Man' Artifacts Found in Northeast Bexar County. La Tierra 4(3):7-9.

Jaquier, J. A.

1977 An Archaeological Survey for the Cibolo Creek Municipal Authority, South Central Texas. Center for Archaeological Research. The University of Texas at San Antonio, Archaeological Survey Report 29.

Johnson, L., Jr., D. A. Suhm, and C. D. Tunnel1

1962 Salvage Archeology of Canyon Reservoir: The Wunderlich, Footbridge, and Oblate Sites. Texas Memorial Museum, Bulletin 5.

Knudson, R.

1983 Organizational Variability in Late Paleo-Indian Assemblages. Washington State University, Laboratory of Anthropology, Reports of Investigations 60 .

Snavely, R.

1983 An Archaeological Survey of Sunrise Canyon Unit 2 Subdivision, Universal City, Northeast Bexar County, Texas. Interim Report. On file, Center for Archaeological Research, The University of Texas at San Antonio.

Taylor, F. B., R. B. Hailey, and D. L. Richmond

1966 Soil Survey of Bexar County, Texas. United States Department of Agriculture, Soil Conservation Service, in cooperation with the Texas Agricultural Experiment Station. 


